\title{
Characteristics of BAFF and APRIL factor expression in multiple myeloma and clinical significance
}

\author{
JING PAN ${ }^{1}$, YUANYUAN SUN ${ }^{1}$, NING ZHANG $^{1}$, JIANMING LI $^{2}$, FANGXIN TA $^{3}$, \\ WEI WEI ${ }^{1}$, SHANSHAN YU ${ }^{1}$ and LIMEI AI ${ }^{1}$ \\ ${ }^{1}$ Department of Hematology, The First Affiliated Hospital of Jinzhou Medical University; \\ ${ }^{2}$ Medical College, Jinzhou Medical University; ${ }^{3}$ Medical Center, The First Affiliated Hospital \\ of Jinzhou Medical University, Jinzhou, Liaoning 121001, P.R. China
}

Received July 21, 2016; Accepted February 10, 2017

DOI: $10.3892 / 01.2017 .6528$

\begin{abstract}
The characteristics of the proliferation of B-cell activating factor (BAFF) and the proliferation-inducing ligand (APRIL) mRNA expression in mononuclear cell in multiple myeloma patients were detected, and the correlation was analyzed between the BAFF and APRIL concentrations in plasma and tumor burden parameters of multiple myeloma. Bone marrow samples from 60 patients with multiple myeloma and 20 healthy persons taken as controls, were collected. Bone marrow mononuclear cells (BMMCs) were harvested, and plasma was extracted. BAFF and APRIL mRNA expression was quantified using real-time fluorescent quantitative PCR in the BMMCs. ELISA was used to detect the characteristics of gene and protein expression of BAFF and APRIL in KM3 cell line. The BAFF and APRIL mRNA expression in initial treatment group, remission group and non-remission group were markedly higher than that in control group $(\mathrm{P}<0.05)$. The expression in initial treatment group and non-remission group was markedly higher than that of the control group $(\mathrm{P}<0.05)$. APRIL mRNA expression in mononuclear cells in stage III patients was markedly higher than that in stage II patients $(\mathrm{P}<0.05)$. There was positive correlation between APRIL and BAFF concentration in multiple myeloma $(\mathrm{P}=0.0027)$. In conclusion, for the gene and protein expression of BAFF and APRIL in patients with multiple myeloma, the initial treatment group and non-remission are higher than control and remission group. The higher the stage was, the more the factors were expressed. Characteristics of expression of BAFF and APRIL may be used as a new index to evaluate the prognosis of multiple myeloma.
\end{abstract}

Correspondence to: Dr Limei Ai, Department of Hematology, The First Affiliated Hospital of Jinzhou Medical University, 2 Renmin Road, Jinzhou, Liaoning 121001, P.R. China

E-mail: limeiai009@163.com

Key words: B-cell activating factor, proliferation, induction, ligand, multiple myeloma, expression

\section{Introduction}

Multiple myeloma (MM) accounts for about $10 \%$ of the hematopoietic system tumors. The incidence rate of multiple myeloma in China is $1 / 10$ million, which is lower than that of western countries of 4/10 million. However, in recent years the incidence rate of multiple myeloma is on the rise, and the age of onset is also increasingly falling (1). In previous years, effective rate of chemotherapy was $40-60 \%$ and the complete remission rate was $<5 \%$. The median survival period was not more than 3 years. At present, multiple myeloma remains a malignant disease of which the therapeutic effect is unsatisfactory $(2,3)$. In recent years, with the intervention of some new drugs, the treatment for myeloma has made some progress, but the complete remission rate is $\sim 30 \%$ (4). Therefore, targeting new markers to further explore the pathogenesis of multiple myeloma and for searching new therapeutics has become important.

It is now considered that the occurrence and development of multiple myeloma is closely related to microenvironment of bone marrow. Many cytokines can promote the growth and survival of tumor cells, such as IL-6 paracrine by bone marrow stromal cells can promote the proliferation of myeloma cells, resisting the cytotoxicity induced by drugs $(5,6)$. In addition, insulin-like growth factor 1 (IGF-1) and hepatocyte growth factor (HGF) are also stimulating signal to multiple myeloma growth, promoting the proliferation and survival of myeloma cells $(7,8)$. The proliferation of B-cell activating factor (BAFF) and the proliferation-inducing ligand (APRIL), new members of tumor necrosis factor (TNF) family, have been identified in recent years. They are the main cytokines that promote the proliferation and survival of B cells and also have similar effects on plasma cells $(2,9)$.

Our study focuses on the gene and protein expression of BAFF and APRIL in bone marrow mononuclear cells (BMMCs) and plasma of patients with multiple myeloma and correlation analysis between multiple myeloma clinical indicators and the gene and protein expression of BAFF and APRIL were performed.

\section{Materials and methods}

Subjects. Multiple myeloma cell line KM3 was purchased from Kangwei Century Biotechnology Co. Ltd. (Beijing, China). 
We regarded 60 patients with multiple myeloma patients as the research objects from February 2011 to May 2013 in the Department of Hematology in the First Affiliated Hospital of Jinzhou Medical University. Thirty-three male cases and 27 female cases were included. The initial treatment was 18 cases. Remission was 25 patients. Non-remission was 17 patients. Twenty-eight cases were immunoglobulin G $(\mathrm{IgG})$ type. Eighteen cases were IgA type. One hundred forty-four cases were light chain type. Sixteen cases were in stage I. Twenty-one cases were in stage II. Twenty-three cases were in stage III. The patients were aged from 30 to 75 years and the median age was 53 years. All the patients conformed to the diagnostic standard of WHO multiple myeloma.

The initial treatment patients were first diagnosed without any treatment. After diagnosed with multiple myeloma, the patients were administered with VAD chemotherapy combined with thalidomide.

We selected 20 patients with mild to moderate iron deficiency anemia in the same period in the Department of Hematology in the First Affiliated Hospital of Jinzhou Medical University as the control group. Eleven patients were male and 9 were female. They were aged from 30 to 65 years. All patients agreed to the use of their samples. This study was approved by the Ethics Committee of The First Affiliated Hospital of Jinzhou Medical University. Signed written informed consents were obtained from the patients and/or guardians.

All patients with multiple myeloma and the control group were excluded from rheumatoid arthritis, systemic lupus erythematosus, central nervous system diseases, infectious diseases and diabetes. The renal function in MM patients was normal or mildly impaired, $\mathrm{Cr}<176.8 \mu \mathrm{mol} / 1$.

Real-time fluorescent PCR primer synthesis: According to the principle of PCR primer design, the primers of BAFF, APRIL and GAPDH were designed with reference to the literature. Primer was synthesized by Schreck Biological Technology Co., Ltd. (Shanghai, China) (7).

BAFF upstream primer was 5'-ACAAACCAGTGAAAA CTAT-3'. BAFF downstream primer was 5'-ATCCTTCCACTA CAAAG-3'. Anticipated product was 282 bp.

APRIL upstream primer was 5'-CCTACGCATTCCTCAA CGAA-3'. APRIL downstream primer was 5'-TAAACTACCT GATCCCAGCA-3'. Anticipated product was $214 \mathrm{bp}$.

GAPDH upstream primer was 5'-AATCCACCTCTCAAC TACC-3'. GAPDH downstream primer was 5'-CTCCCCACGC AAGCTTAC-3'. Anticipated product was $359 \mathrm{bp}$.

KM3 cell culture. Under sterile conditions, KM3 cells were inoculated into the RPMI-1640 medium containing 10\% fetal bovine serum. Then it was placed in the incubator with 5\% carbon dioxide, $37^{\circ} \mathrm{C}$ saturated humidity to be cultured. Then renewed every 2-3 days.

BMMCs collection. Under sterile conditions, $5 \mathrm{ml}$ bone marrow from patients with multiple myeloma and control group was extracted and added with heparin (1:10). The fresh bone marrow specimens were carefully added on the lymphocyte separation medium. Then it was centrifuged for $10 \mathrm{~min}$ at $1,500 \mathrm{xg}$. The mononuclear cells in the middle layer were collected. After centrifugation for $10 \mathrm{~min}$ at $700 \mathrm{x} \mathrm{g}$, the supernatant was absorbed and then precipitated by $1 \mathrm{X}$ PBS
(Beckman Coulter, Brea, CA, USA) and washed 3 times to obtain cells.

BMMCs RNA extraction. BMMCs $\left(2 \times 10^{6}\right)$ were extracted and were carefully prepared in an environment which was absent of enzyme. Cells were precipitated in $1 \mathrm{ml}$ TRIzol solution (Invitrogen, Carlsbad, CA, USA), fully blown uniformly and placed at room temperature for $5 \mathrm{~min}$. Chloroform solution of $0.3 \mathrm{ml}$ was added, mixed, placed at room temperature for $5 \mathrm{~min}, 4^{\circ} \mathrm{C} 8,000 \mathrm{x}$ g centrifuged for $15 \mathrm{~min}$ and supernatant was taken. In the EP tube (Beckman Coulter) with supernatant, an equal volume of cold isopropanol solution was added, mixed, placed at room temperature for $30 \mathrm{~min}$ and $4^{\circ} \mathrm{C} 8,000 \times \mathrm{g}$ centrifuged for $10 \mathrm{~min}$. Supernatant was discarded carefully. The gelatinous precipitate on the tube wall was RNA. Seventyfive percent $0.5 \mathrm{ml}$ ethanol solution (Beckman Coulter) was added, shaking and washing the precipitate. Centrifuged at $3,000 \mathrm{x} \mathrm{g}$ at $4^{\circ} \mathrm{C}$ for $5 \mathrm{~min}$, discarding supernatant, dried at room temperature for $30 \mathrm{~min}$. DEPC water $(10 \mathrm{ml}$; Beckman Coulter) was added, dissolving the precipitation and mixed. The mixture was the RNA extract.

Qualitative and quantitative determination of RNA. One microliter RNA extract was taken and $49 \mu 1$ DEPC water was added. With UV visible spectrophotometer (Auxi Scientific Instrument Co. Ltd., Shanghai, China), we measured OD280 and OD260 value in each tube to calculate the content of RNA in each sample, and obtain the ratio.

$m R N A$ reverse transcription to $c D N A$. With reverse transcription kit, mRNA was reverse transcribed to cDNA. Steps are as follows: i) $5 \mu \mathrm{g}$ total RNA was taken, and $1 \mu \mathrm{l}$ random primers was added. DEPC water was added to a total volume of $12 \mu \mathrm{l}$. Degeneration at $70^{\circ} \mathrm{C}$ for $5 \mathrm{~min}$; ii) $5 \mathrm{X}$ buffer $4 \mu \mathrm{l}$, $2 \mu 110 \mathrm{mmol} / \mathrm{l} \mathrm{dNTP}$ and ribonuclease inhibitor $\mu 1$ mixtures were added after reverse transcriptase $1 \mu \mathrm{l}$ was added, and placed at room temperature for $5 \mathrm{~min}$; iii) $42^{\circ} \mathrm{C}$ for $1 \mathrm{~h}, 99^{\circ} \mathrm{C}$ for $5 \mathrm{~min}$; and iv) after the reaction was over, it was placed on ice to cool for $2 \mathrm{~min}$. The synthesized cDNA template was preserved at $-20^{\circ} \mathrm{C}$.

Fluorescence quantitative PCR. SYBR-Green I fluorescent was used to perform quantitative PCR reaction. The reaction system: $2 \mu \mathrm{l}$ template, primer $1 \mu \mathrm{l}$, and was mixed with $10 \mu \mathrm{l}$ dye mixture. Ultrapure water was added to $20 \mu 1$. After mixed evenly, it was placed into the PCR thermal cycler for reaction. After each cycle of degeneration, the program can automatically record the average fluorescence values of the last cycle of the last $10 \%$ of time, which indicates the amount of PCR products when last cycle ends. After the reaction was completed, recorded curves of all samples were obtained.

Plasma samples collection. When BMMCs were collected, plasma was collected at the same time. The plasma was packed in aseptic EP tubes of $1 \mathrm{ml}$ and was preserved at $-20^{\circ} \mathrm{C}$.

The determination of BAFF and APEIL with ELISA. The enzyme label plate was taken out. One hundred microliters standard substance was added respectively in the blank pores 
Table I. The expression of BAFF mRNA in BMMCs of the four groups of patients.

\begin{tabular}{lcc}
\hline Groups & Number & BAFF mRNA corrected value \\
\hline Control & 20 & $0.81 \pm 0.34$ \\
Initial treatment & 18 & $2.83 \pm 0.45^{\mathrm{a}, \mathrm{b}}$ \\
Remission & 25 & $1.52 \pm 0.26^{\mathrm{a}}$ \\
Non-remission & 17 & $2.44 \pm 0.37^{\mathrm{a}, \mathrm{b}}$ \\
\hline
\end{tabular}

${ }^{\mathrm{a}} \mathrm{P}<0.05$ vs. control group; ${ }^{\mathrm{b}} \mathrm{P}<0.05$ vs. remission group. BAFF, B-cell activating factor; BMMCs, bone marrow mononuclear cells.

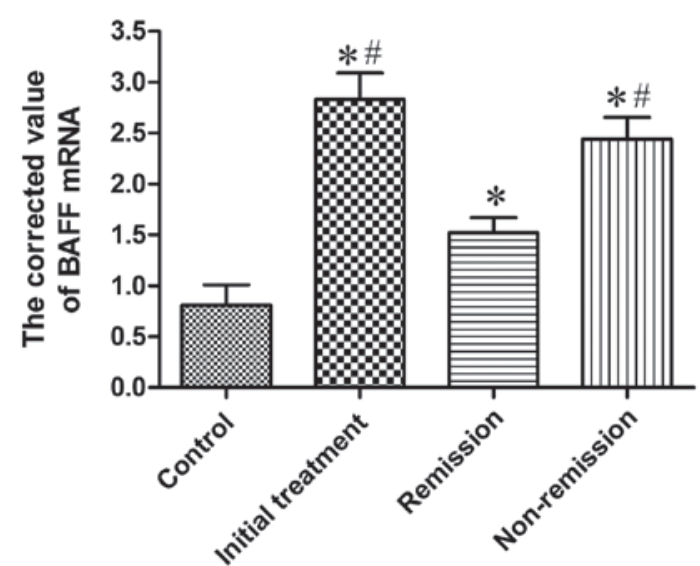

Figure 1. The expression of BAFF mRNA in BMMCs of the four groups of patients. ${ }^{*} \mathrm{P}<0.05$ vs. control group; ${ }^{\#} \mathrm{P}<0.05$ vs. remission group. BAFF, $\mathrm{B}$-cell activating factor; BMMCs, bone marrow mononuclear cells.

and the pores were labeled. Fifty microliters enzyme-marked solution was added to standard sample holes and sample holes and incubated for $60 \mathrm{~min}$ at $37^{\circ} \mathrm{C}$. Concentrated washing liquid and medical distilled water were diluted at 1:20. Microtiter plate was washed 5 times repeatedly, each time for $30 \mathrm{sec}$. Fifty microliters substrate A, B was added to each hole, incubated for $15 \mathrm{~min}$ at $37^{\circ} \mathrm{C}$. Fifty microliters of the termination liquid was added to each hole to terminate reaction. OD value was obtained in the enzyme-linked immunosorbent assay (ELISA) (Bio-Rad, Philadelphia, PA, USA) (10).

Statistical analysis. SPSS 15.0 (IBM, Chicago, IL, USA) was used for the statistical analysis. The homogeneity of variance for the sample data was tested. According to the homogeneity of variance, one-way analysis of variance and rank test were used. The results are expressed as mean \pm standard deviation (mean $\pm \mathrm{SD}$ ), $\mathrm{P}<0.05$ was considered to indicate a statistically significant difference.

\section{Results}

Expression of BAFF mRNA in BMMCs of the four groups of patients. Real-time fluorescent quantitative RT-PCR was used to determine BAFF mRNA expression in mononuclear cells in bone marrow of 20 cases of the control group, 20 cases of initial treatment group, 8 cases of remission group and 6 cases
Table II. The expression of BAFF mRNA in BMMCs of patients in different stages.

\begin{tabular}{lcc}
\hline Groups & Number & mRNA corrected value \\
\hline Stage I & 16 & $1.36 \pm 0.51$ \\
Stage II & 21 & $1.62 \pm 0.58$ \\
Stage III & 23 & $1.67 \pm 0.64$ \\
\hline
\end{tabular}

BAFF, B-cell activating factor; BMMCs, bone marrow mononuclear cells.

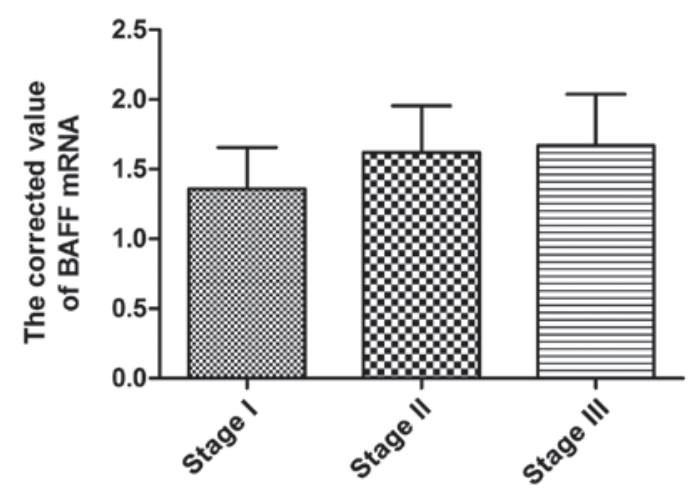

Figure 2. The expression of BAFF mRNA in BMMCs of patients in different stages. BAFF, B-cell activating factor; BMMCs, bone marrow mononuclear cells.

from non-remission group. BAFF mRNA was positively expressed in patients with MM and 20 cases of control group, and the corrected value is shown in Table I and Fig. 1. The results suggested that the quantitative PCR corrected value of initial treatment group was markedly higher than that of control group, which was statistically different $(\mathrm{P}<0.05)$; the quantitative PCR corrected value in remission group were significantly higher than that of the control group, and the difference was significant $(\mathrm{P}<0.05)$; the quantitative PCR corrected value in non-remission group was obviously higher than that in the control group, and the difference was significant $(\mathrm{P}<0.05)$; the quantitative $\mathrm{PCR}$ corrected value in initial treatment group was significantly higher $(\mathrm{P}<0.05)$ than that in remission group; the quantitative PCR corrected value in non-remission group was significantly higher $(\mathrm{P}<0.05)$ than that in remission group; the quantitative PCR corrected value in initial treatment group and in non-remission group showed no significant difference.

Expression of BAFF mRNA in BMMCs of patients in different stages. According to ISS stage standard, 60 patients with multiple myeloma were divided into 16 patients in stage I, 21 patients in stage II and 23 patients in stage III. The results showed that BAFF mRNA expression in mononuclear cells of patients in different stages had no significant difference (Table II and Fig. 2).

Expression of APRIL mRNA in BMMCs of the four groups of patients. APRIL mRNA was positively expressed in patients with MM and 10 cases of control group, and the corrected 
Table III. The expression of APRIL mRNA in BMMCs of the four groups of patients.

\begin{tabular}{lcc}
\hline Groups & Number & mRNA corrected value \\
\hline Control & 20 & $0.64 \pm 0.27$ \\
Initial treatment & 18 & $1.95 \pm 0.62^{\mathrm{a}, \mathrm{b}}$ \\
Remission & 25 & $1.33 \pm 0.52^{\mathrm{a}}$ \\
Non-remission & 17 & $1.87 \pm 0.63^{\mathrm{a}, \mathrm{b}}$ \\
\hline
\end{tabular}

${ }^{\mathrm{a}} \mathrm{P}<0.05$ vs. control group, ${ }^{\mathrm{b}} \mathrm{P}<0.05$ vs. remission group. APRIL, a proliferation-inducing ligand; $\mathrm{BMMCs}$, bone marrow mononuclear cells.

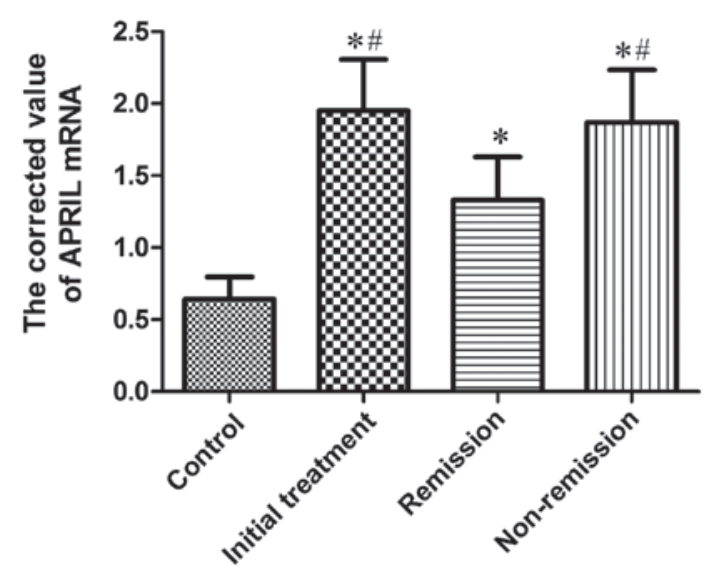

Figure 3. The expression of APRIL mRNA in BMMCs of the four groups of patients. ${ }^{*} \mathrm{P}<0.05$ vs. control group, ${ }^{\#} \mathrm{P}<0.05$ vs. remission group. APRIL, a proliferation-inducing ligand; BMMCs, bone marrow mononuclear cells.

value is shown in Table III and Fig. 3. The results suggested that: The quantitative PCR corrected value of initial treatment group was markedly higher than that of control group, which was statistically different $(\mathrm{P}<0.05)$; the quantitative PCR corrected value in remission group were significantly higher $(\mathrm{P}<0.05)$ than that of the control group; the quantitative PCR corrected value in non-remission group was obviously higher than that in the control group, and the difference was significant $(\mathrm{P}<0.05)$; the quantitative PCR corrected value in initial treatment group was significantly higher than that in remission group, which was statistically different $(\mathrm{P}<0.05)$; the quantitative PCR corrected value in non-remission group was significantly higher than that in remission group, and the difference was significant $(\mathrm{P}<0.05)$; the quantitative PCR corrected value in initial treatment group and in non-remission group showed no significant difference.

Expression of APRIL mRNA in BMMCs of patients in different stages. APRIL mRNA expression in BMMCs in stage III patients was significantly higher than that in stage II patients, and the difference was significant $(\mathrm{P}<0.05)$; compared with stage I patients, there was no significant difference ( $\mathrm{P}>0.05)$ (Table IV and Fig. 4).

Gene and protein expression of BAFF/APRIL in KM3 cell line. Real-time fluorescent quantitative RT-PCR was employed
Table IV. The expression of BAFF mRNA in BMMCs of patients in different stages.

\begin{tabular}{lcc}
\hline Groups & Number & mRNA corrected value \\
\hline Stage I & 16 & $1.14 \pm 0.47$ \\
Stage II & 21 & $0.83 \pm 0.38$ \\
Stage III & 23 & $1.42 \pm 0.56^{\mathrm{a}}$ \\
\hline
\end{tabular}

${ }^{\mathrm{a}} \mathrm{P}<0.05$ vs. patients in stage II. BAFF, B-cell activating factor; BMMCs, bone marrow mononuclear cells.

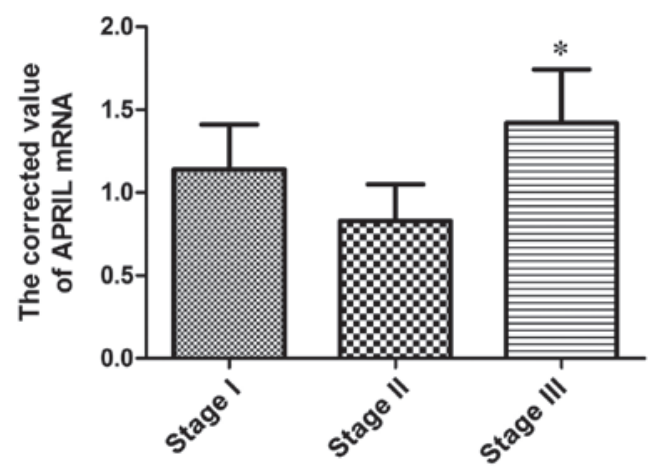

Figure 4. The expression of APRIL mRNA in BMMCs of patients in different stages. APRIL, a proliferation-inducing ligand; BMMCs, bone marrow mononuclear cells. ${ }^{*} \mathrm{P}<0.05$ vs. stage II group.

Table V. The gene and protein expression of BAFF/APRIL in KM3 cell line.

\begin{tabular}{lcc}
\hline Cytokine & $\begin{array}{c}\text { mRNA corrected } \\
\text { value }\end{array}$ & $\begin{array}{c}\text { Protein concentration } \\
(\mathrm{ng} / \mathrm{ml})\end{array}$ \\
\hline BAFF & 0.8351 & 6.8204 \\
APRIL & 0.7134 & 3.5913 \\
\hline
\end{tabular}

BAFF,B-cell activating factor;APRIL, a proliferation-inducing ligand.

to determine BAFF and APRIL gene expression in KM3 cell line. BAFF and APRIL protein concentration was detected with ELISA (Table V).

The relationship between BAFF/APRIL expression and clinical parameters of patients with multiple myeloma. ELISA was used to detect the expression of BAFF and APRIL, and the clinical data of these patients were collected: Peripheral blood hemoglobin $(\mathrm{Hb})$ concentration, albumin (ALB) content, $\mathrm{Ig}, \mathrm{A} / \mathrm{G}, \beta-2$ microglobulin $(\beta-2 \mathrm{MG})$ and plasma cell ratio in bone marrow. The relationship between BAFF and APRIL expression and the parameters mentioned above was analyzed. We found that there was negative correlation between APRIL concentration and ALB in peripheral blood ( $\mathrm{P}=0.0346)$. APRIL concentration was positively correlated with $\beta$-2MG $(\mathrm{P}=0.0013)$, Ig $(\mathrm{P}=0.0082)$, plasma cell ratio in bone marrow $(\mathrm{P}=0.0027)$. APRIL concentration had no significant correlation with other parameters, such as $\mathrm{Hb}$ content. BAFF 
Table VI. The relationship between BAFF/APRIL expression and clinical parameters of patients with multiple myeloma.

\begin{tabular}{|c|c|c|c|c|}
\hline \multirow[b]{2}{*}{ Clinical data } & \multicolumn{2}{|c|}{ APRIL (ng/ml) } & \multicolumn{2}{|c|}{ BAFF (ng/ml) } \\
\hline & Correlation coefficient & P-value & Correlation coefficient & P-value \\
\hline $\mathrm{Hb}(\mathrm{g} / \mathrm{l})$ & -0.4013 & 0.1652 & -0.3615 & 0.2164 \\
\hline $\operatorname{ALB}(g / 1)$ & -0.4627 & $0.0346^{\mathrm{a}}$ & -0.6249 & $0.0024^{b}$ \\
\hline $\operatorname{Ig}(\mathrm{g} / \mathrm{l})$ & 0.7036 & $0.0082^{\mathrm{b}}$ & 0.5932 & $0.0384^{\mathrm{a}}$ \\
\hline $\mathrm{A} / \mathrm{G}(\%)$ & -0.3263 & 0.1935 & -0.5127 & $0.0218^{\mathrm{a}}$ \\
\hline$\beta-2 \mathrm{MG}(\mathrm{mg} / \mathrm{l})$ & 0.8334 & $0.0013^{b}$ & 0.4935 & $0.0402^{\mathrm{a}}$ \\
\hline Plasma cell (\%) & 0.8052 & $0.0027^{\mathrm{b}}$ & 0.6814 & $0.0019^{b}$ \\
\hline APRIL (ng/ml) & & & 0.6013 & $0.0027^{\mathrm{b}}$ \\
\hline
\end{tabular}

${ }^{\mathrm{a}} \mathrm{P}<0.05,{ }^{\mathrm{b}} \mathrm{P}<0.01$. BAFF, B-cell activating factor; APRIL, a proliferation-inducing ligand; Hb, hemoglobin; ALB, albumin; Ig, immunoglobulin; $\beta-2 \mathrm{MG}, \beta-2$ microglobulin.

concentration was negatively correlated to ALB $(\mathrm{P}=0.0024)$ and $\mathrm{A} / \mathrm{G}(\mathrm{P}=0.0218)$, and was positively correlated to $\beta-2 \mathrm{MG}$ $(\mathrm{P}=0.0402), \mathrm{Ig}(\mathrm{P}=0.0384)$ and plasma cell ratio in bone marrow $(\mathrm{P}=0.0019)$. It had no significant correlation with the content of $\mathrm{Hb}$. APRIL was positively correlated to BAFF in multiple myeloma $(\mathrm{P}=0.0027)$ (Table VI).

\section{Discussion}

BAFF and APRIL are newly-discovered members of the TNF family. They promote the growth and proliferation of B lymphocytes. Accordingly, exploring its relationship with blood B lymphocyte malignancies has been the focus of research. It was suggested that BAFF was necessary for the survival of normal immature and mature B cells, and is also necessary for the growth of the normal plasma blasts $(11,12)$. BAFF also plays a key role in the survival of the tumor cells in B-CLL (13). In addition, APRIL can stimulate some human and rat tumor cell growth in vivo and in vitro (14). Therefore, we chose the lymphoid proliferation factor BAFF and APRIL, and observe their expression in patients with multiple myeloma.

Srinivasan and Schiffer firstly found that myeloma cell expressed BAFF and APRIL. They also detected the concentration of soluble BAFF and APRIL in the serum of patients with multiple myeloma, which was 5 times that of normal people of the same age (15).

With ELISA, Ilić et al analyzed the average concentration of BAFF level in 51 patients with myeloma patients and 11 normal people. The result was 968 and $417 \mathrm{pg} / \mathrm{ml}$, respectively, which was statistically different (16).

Fluorescent quantitative PCR was employed to detect the expression of BAFF and APRIL mRNA in BMMCs in 60 cases with multiple myeloma and control group. The results showed that the expression of BAFF and APRIL mRNA of initial treatment group, non-remission group and remission group patients were higher than that in control group. The initial treatment group and non-remission group were higher than the remission group, which suggested that BAFF and APRIL were highly expressed in multiple myeloma and the two factors decreased after treatment. Such changes of BAFF and APRIL existed in the whole process of $\mathrm{MM}$, which are useful indicators to judge the remission state of multiple myeloma and may be the main tumor promoter in multiple myeloma.

Mechanisms by which BAFF and APRIL promote the survival and proliferation of B lymphocytes are closely related to BCMA, TACI and BAFF-R9 (17). BAFF-R has high affinity for BAFF, which mainly regulates the growth of normal B cells (18). BCMA and TACI are main receptors which maintain the multiple myeloma cell proliferation and survival $(19,20)$. The main mechanisms are: BAFF/APRIL binds to its receptor BCMA, TACI and induces $N F-\kappa B$, $\mathrm{P} 13 / \mathrm{AKT}$ and MAPK signal pathway to increase the expression of anti-apoptotic protein $\mathrm{Mcl}-1$ and $\mathrm{Bcl}-2$, inhibiting the apoptosis of myeloma cells and promoting their proliferation and survival $(21,22)$. Ho et al found that bone marrow stromal cells in the bone marrow microenvironment could produce BAFF, and found that the concentration of BAFF in bone marrow stromal cells was 3-10 times that of myeloma cells by flow cytometry (23). When myeloma cell adheres to bone marrow stromal cells, BAFF produced by bone marrow stromal cell increased 2-5 times compared with BAFF produced by single bone marrow stromal cells $(24,25)$. At the same time, the increase of BAFF expression in turn promotes myeloma cell adhesion to bone marrow stromal cells, which has dose-effect relationship (26). Osteoclasts in multiple myeloma microenvironment produce a large number of APRIL by paracrine to promote the occurrence and development of myeloma (27).

In order to understand whether the expression of BAFF/APRIL is associated with the severity of multiple myeloma, patients with multiple myeloma were divided into stage I, II and III according to the clinical stage of ISS. The results suggest that expression of APRIL mRNA in BMMCs in stage III patients was significantly higher than that in stage II patients, which is statistically different. We may consider that the expression of BAFF and APRIL mRNA in $\mathrm{MM}$ clinical staging has the tendency for the expression to increase with the increasing of staging. The main cause is that Patients with high clinical stage get less opportunity to be relieved, and the bone marrow microenvironment often appears as a neoplastic proliferation alteration, resulting in the increase of BAFF/APRIL expression. However, APRIL 
is widely produced by the bone marrow microenvironment cells and extramicroenvironment cells, so the plasma concentration is often higher than BAFF and is sensitive when detected.

\section{References}

1. Sanchez E, Li M, Kitto A, Li J, Wang CS, Kirk DT, Yellin O, Nichols CM, Dreyer MP, Ahles CP, et al: Serum B-cell maturation antigen is elevated in multiple myeloma and correlates with disease status and survival. Br J Haematol 158: 727-738, 2012.

2. Fragioudaki M, Boula A, Tsirakis G, Psarakis F, Spanoudakis M, Papadakis IS, Pappa CA and Alexandrakis MG: B cell-activating factor: its clinical significance in multiple myeloma patients. Ann Hematol 91: 1413-1418, 2012

3. Tsukada Y, Hattori Y, Nakajima H, Yokoyama K, Murata M, Shimizu N, Kondo N and Okamoto S: B-cell acute lymphoblastic leukemia developed 5 years after autologous stem cell transplantation for multiple myeloma. Rinsho Ketsueki 53: 219-223, 2012 (In Japanese).

4. Jöhrer K, Hofbauer SW, Zelle-Rieser C, Greil R and Hartmann TN: Chemokine-dependent B cell-T cell interactions in chronic lymphocytic leukemia and multiple myeloma - targets for therapeutic intervention? Expert Opin Biol Ther 12: 425-441, 2012

5. Kurzrock R, Voorhees PM, Casper C, Furman RR, Fayad L, Lonial S, Borghaei H, Jagannath S, Sokol L, Usmani SZ, et al: A phase I, open-label study of siltuximab, an anti-IL-6 monoclonal antibody, in patients with B-cell non-Hodgkin lymphoma, multiple myeloma, or Castleman disease. Clin Cancer Res 19: 3659-3670, 2013

6. Reijmers RM, Spaargaren M and Pals ST: Heparan sulfate proteoglycans in the control of B cell development and the pathogenesis of multiple myeloma. FEBS J 280: 2180-2193, 2013.

7. Wang SM, Zhang TL, Jiang YM, Wu HY, Hao LM and Xing XH: Expression and significance of $\mathrm{B}$ cell-activating factor of TNF family (BAFF) and B cell lymphoma/leukemia-2 (BCL-2) in multiple myeloma. Zhongguo Shi Yan Xue Ye Xue Za Zhi 19: 395-398, 2011 (In Chinese).

8. Carpenter RO, Evbuomwan MO, Pittaluga S, Rose JJ, Raffeld M, Yang S, Gress RE, Hakim FT and Kochenderfer JN: B-cell maturation antigen is a promising target for adoptive T-cell therapy of multiple myeloma. Clin Cancer Res 19: 2048-2060, 2013.

9. Boucher K, Parquet N, Widen R, Shain K, Baz R, Alsina M, Koomen J, Anasetti C, Dalton W and Perez LE: Stemness of $\mathrm{B}$-cell progenitors in multiple myeloma bone marrow. Clin Cancer Res 18: 6155-6168, 2012.

10. Goel A, Spitz DR and Weiner GJ: Manipulation of cellular redox parameters for improving therapeutic responses in B-cell lymphoma and multiple myeloma. J Cell Biochem 113: 419-425, 2012

11. Mahtouk K, Tjin EP, Spaargaren M and Pals ST: The HGF/MET pathway as target for the treatment of multiple myeloma and B-cell lymphomas. Biochim Biophys Acta 1806: 208-219, 2010.

12. Hollander $\mathrm{N}$ : Current vaccination strategies for the treatment of B-cell lymphoma and multiple myeloma. Crit Rev Immunol 29: 399-418, 2009

13. Chen P, Li B, Zhuang W, Huang H, Zhang H and Fu J: Multiple bone lesions and hypercalcemia presented in diffuse large $\mathrm{B}$ cel lymphoma: mimicking multiple myeloma? Int J Hematol 91: 716-722, 2010
14. Harding SJ, Mead GP, Bradwell AR and Berard AM: Serum free light chain immunoassay as an adjunct to serum protein electrophoresis and immunofixation electrophoresis in the detection of multiple myeloma and other B-cell malignancies. Clin Chem Lab Med 47: 302-304, 2009.

15. Srinivasan S and Schiffer CA: Concurrent B-cell chronic lymphocytic leukemia and multiple myeloma treated successfully with lenalidomide. Leuk Res 33: 561-564, 2009.

16. Ilić V, Milosević-Jovcić N, Petrović S, Marković D, Stefanović $G$ and Ristić T: Glycosylation of $\operatorname{IgG}$ B cell receptor (IgG BCR) in multiple myeloma: relationship between sialylation and the signal activity of IgG BCR. Glycoconj J 25: 383-392, 2008.

17. Fragioudaki M, Tsirakis G, Pappa CA, Aristeidou I, Tsioutis C, Alegakis A, Kyriakou DS, Stathopoulos EN and Alexandrakis MG: Serum BAFF levels are related to angiogenesis and prognosis in patients with multiple myeloma. Leuk Res 36: 1004-1008, 2012.

18. Shen X, Zhang X, Xu G and Ju S: BAFF-R gene induced by IFN- $\gamma$ in multiple myeloma cells is related to NF- $\kappa$ B signals. Cell Biochem Funct 29: 513-520, 2011.

19. Shen X, Zhu W, Zhang X, Xu G and Ju S: A role of both $\mathrm{NF}-\kappa \mathrm{B}$ pathways in expression and transcription regulation of BAFF-R gene in multiple myeloma cells. Mol Cell Biochem 357: 21-30, 2011

20. Li LS, Shen JK and Zhang GS: Effect of BAFF/APRIL mRNA expression induced by glucocorticoid and bortezomib in multiple myeloma cells in vitro. Zhongguo Shi Yan Xue Ye Xue Za Zhi 19: 1419-1423, 2011 (In Chinese).

21. Quinn J, Glassford J, Percy L, Munson P, Marafioti T, RodriguezJusto M and Yong K: APRIL promotes cell-cycle progression in primary multiple myeloma cells: influence of D-type cyclin group and translocation status. Blood 117: 890-901, 2011.

22. Moreaux J, Sprynski AC, Dillon SR, Mahtouk K, Jourdan M, Ythier A, Moine P, Robert N, Jourdan E, Rossi JF, et al: APRIL and TACI interact with syndecan-1 on the surface of multiple myeloma cells to form an essential survival loop. Eur J Haematol 83: 119-129, 2009.

23. Ho J, Yang L, Banihashemi B, Martin L, Halpenny M, Atkins H, Sabloff M, McDiarmid SA, Huebsch LB, Bence-Bruckler I, et al: Contaminating tumour cells in autologous PBSC grafts do not influence survival or relapse following transplant for multiple myeloma or B-cell non-Hodgkin's lymphoma. Bone Marrow Transplant 43: 223-228, 2009.

24. Peh SC, Gan GG, Lee LK and Eow GI: Clinical relevance of CD10, BCL-6 and multiple myeloma-1 expression in diffuse large B-cell lymphomas in Malaysia. Pathol Int 58: 572-579, 2008.

25. Ianotto JC, Tempescul A, Eveillard JR, Marion V, Quintin-Roué I and Berthou C: Tri-lineage disease involving sideroblastic anaemia, multiple myeloma and B-cell non-Hodgkin's lymphoma in the same patient. Ann Hematol 88: 273-274, 2009.

26. Kuiper R, Broyl A, de Knegt Y, van Vliet MH, van Beers EH, van der Holt B, el Jarari L, Mulligan G, Gregory W, Morgan $\mathrm{G}$, et al: A gene expression signature for high-risk multiple myeloma. Leukemia 26: 2406-2413, 2012.

27. Novak AJ, Grote DM, Ziesmer SC, Rajkumar V, Doyle SE and Ansell SM: A role for IFN-lambdal in multiple myeloma B cell growth. Leukemia 22: 2240-2246, 2008. 